\title{
DE PEPERKULTUUR IN BENKOELEN EN DE LAMPONGSCHE DISTRIKTEN.
}

Tot behoud van de kolone,

Leve de waarheid I

Toen in 1596 Cornelis Houtman voor het eerst Sumatra's westkust bezocht, dreven de Fngelschen daar reeds gedurende vele jaren bandel, roornamelijk in peper. Van lieverlede slaagden zij er in, kantoren te vestigen in Atjin, te Ajer Bangies, Priaman, Padang, Mendjoeta, Bantal, Selibar, later tot Krö̈, en hoewel de Hollanders ook bier en darr, zooals onder anderen te Indrapoera, vasten voet kregen, zoo bleven zij toch gedurende geruimen tijd meester van de voornanmste peperhavens van Atjin tot aan de Tlakke hoek. De peper van Lampong werd tot het jaar 1808 grootendeels door de Bantamsche vorsten opgekocht; dit was ook het geval met die ran Benkoelen tot 1685, het jaar waarin de Engelsobe kompagnie rich voor goed darr vestigde. Op verschillende plaatsen aan de Westkust van Sumatra was dus reeds vóór 1596 de peperkultuur inheemsch en dat de opbrengst belangrijk was, blijkt uit de vnnnigheiq waarmede Hollanders, Engelschen en Portugezen om het bezit daarvan streden. Marsden zegt dat de opbrengst der Engelsche kantoren jaarlijks 1200 ton van 1600 weight, zijnde nagenoeg 15,600 pikols bedroeg.

In Atjin waren de meeste pepertuinen het eigendom van hoofden en aanzienlijken en werden ze, zoo als daar nu nog het geval is, door slaven of pandelingen bewerkt. In de andere streken werd die kultuur grootendeels door de bevolking, anngemoedigd door geschenken en een redelijke winst, geheel vrijwllig gedreven. Wel deden de hoofden hun best om aan die kultuur uitbreiding te geven. Zij badden daarbij belang, omdat zij zich op die wijze den steun en de goede gunsten van den Bantamschen vorst verzekerden en geschenken en titels verkregen, maar dwang kon door hen niet uitgeoefend worden, daartoe hadden zij geen macht. 
Toen de Engelsche kompagne zich roor goed te Benkoelen vestigde, werden met de hoofden overeenkomsten gesloten warbij deze zich rerbonden door' hunne onderboorigen peper te doen planten en het produkt aan de kompagne te leveren, waarvoor hun bescherming zou worden verleend, hun gezag zou worden gesteund en hun een recht per Bakor van de uit hun distrikt of kampong geleverde peper ten bedrage van 2 spaansche dollars, zijnde $f 1,45$ per pikol, zou worden betaald De planters ontvingen $f 11$ per pikol voor de zwarte en $f 15$ voor de witte peper, terwyl jaarlijks geschenken werden uitgedeeld aan hoofden en planters die het meeste produkt hadden geleverd.

Omtrent dit monopolie zegt Marsden (3e ed. blz. 130) „This low price, at which the natives submit to cultivate their plantations, affording to each man an income of not more than from eight to twelve dollars yearly, and the undisturbed monopoly we have long possessed of the trade, from near Indrapoera northward to Flatpoint southward, are doubtless to a principal degree to be attributed to the peculiar manner in which this port of the island is shut up, by the surfs which prevail along the southwest coast, from communication which strangers, whose competition would naturally produce the effect of enhancing the price of the commodity"....... „thus it appears that these natural obstructions, which we are used to lament as the greatest detriment to our trade, are in fact advantages to which it in a great maesure owes its existence. So in the northern countrie of the island, where the people are numerous and their ports good, they are found to be more independent also, and refuse to cultivate plantations upon any other terms than those on which they can deal with private traders."

Inderdaad is Benkoelen het eenige land op Sumatra waar een verplicht kultuur- en monopoliestelsel is ingevoerd. Op de koffiekultuur te Padang en bovenlanảen is dit slechts langzamerhand toegepast en steeds onder verzachtende vormen; daarbij is zooveel mogelijk schijn van dwang vermeden.

De levering en opkoop van peper geschiedde eens per jaar. Op de strandplaats van ieder distrikt waar zich een pakhuis bevond, en dat was alleen op de enkele plaatsen van waar het transport over zee naar de hoofdplaats Benkoelen kon geschieden, werd een vereeniging of koempoelen gehouden, waarop de planters van heinde ver werden uitgenoodigd met hunne peper en hunne yegchthanen te verschijnen. De peper, die meest met vlotten de 
rivieren werd afgevoerd en vervolgens langs het strand moest worden gepikkeld, kon niet voor dat ze gedroogd en gewand was, in ontrangst worden genomen Intusschen nam het spel een aanvang warbij gewoonlijk de hoofden on kompagnies-dienaren met de verdiensten van de onnoozele planters gingen strijken. Toch kwamen deze door het spel gelokt, telken jare met hunne peper naar beneden, zoolang zij althans hunne vrijheid behielden, want velen moesten die verliezen na vrouw en kinderen verspeeld te bebben. De residenten of agenten van de kompagnie in de afdeelingen waren meestal de geldschreters die tevens zorgden voor den afzet der pandelingen naar de hoofdplaats, waar ze in de notentuinen werden te werk gesteld. Bij de koempoelens waren het ook deze en andere ondergeschikte beambten die met boofden en vreemde kooplieden een winstgevenden handel in lijnwaden en snuisterijen dreven en deze op voordeelige wijze bij de planters tegen peper inruilden. Het schijnt intusschen dat door al deze praktijken de aanmoedıging der hoofden niet voldoende was om de opgezetenen voortdurend smaak te doen vinden in do peperkultuur, en er eenige dwang werd vereischt om deze op een gewenschte hoogte te houden Van heverlede kwam een stelsel ran boeten in zwang, dat de hoofden, gesteund door de kompagnie, in staat stelde hunne onderhoorigen te dwingen on zich zelf tevens te verrijken. L'appétit vient en mangeant, de ijver der hoofden in 't beboeten nam gaandeweg toe. Voor het minste vergrïp moest de planter betalen $\mathrm{De}$ in de tuinen staande grashalmpjes, natuurlijk de hoogsten, werden gemeten met stapels Spaansche dollars die dan het bedrag van de boeten die geëischt werd uitmaakten. Had de ongelukkige geen geld, dan maar een broeder, zuster of kind verpand; had hij die net meer, dan moest hij er zelf aan gelooven Op die wijze scheen het voor de hoofden gemakkelijk weerspannige onderdanen te verwijderen en meer en meer gezag te krijgen.

Velen kwamen echter hiertegen op, trokken naar afgelegene Talangs en weigerden bet bestuur te gehoorzamen. Meer en meer ontstond een geest van verzet; het aantal misdrijven nam toe, het was geen zeldzaamheid dat dienaren van de kompagnie vermoord werden. De hoofden, bevreesd bun invloed geheel te verliezen, speelden een dubbelzinnige rol en waren net te vertrouwen. Van Celebes, Madura, Balı en elders werden hoofden met hunne volgelingen ontboden om in de binnenlanden gezag te voeren en als beambten te worden geplaatst. 
In vele afdeolingen werden de landshoofden nu geheel aan deze vreemdelingen ondergeschikt, hetgeen ongenoegen en wrevel deed ontstaan, nog voor kort geleden waren bijna alle inlandsche beambten in Benkoelen afstanmelingen dezer vreemdelingen. Zij hebben in dat gewest veel kwaad gedaan en veel kwaad bloed gezet.

Onder die omstandigheden ging de peperkultuur niet vooruit, en toen in 1825 Benkoelen onder het Nederlandsch gezag kwam, bedroeg de geheele opbrengst niet veel meer dan 4000 pikols. In de eerste jaren van ons bestuur kwam er in den toestand geene verbetering; wel nam in $1850-1852$ de peperproduktie eenigzins toe, dank zij den ijver van den adsistent-resident P. C. van Royen bijgestaan door den bekwamen gezaghebber N. Hewetson, en klom tot 6000 pikols, maar de algemeene staat van zaken bleef slecht, dezelfde oorzaken hadden, ondanks beleid en ijver onder ons bestuur, dezelfde gevolgen als vroeger. De Engelsche methode om peper te verkrijgen was nog altijd in gebruik, alleen met dit verschil dat de betaling aan de planters was verminderd tot $f 6,50$ voor de pikol zwarte, en $f 8,50$ voor de witte, en die aan de hoofden van $f 0,50$ tot $f$ 1. -

De 82000 planters ontringen gemiddeld ieder $f 2,00$ 's jaars voor $\frac{1}{3}$ pikol die als doorslag geleverd werd, en moesten alvorens zij dit bedrag ontvingen, aan boeten enz. veel meer betalen.

Met een matige geldelijke belasting die met veel minder dwang had kunnen verkregen worden, hadden de bestuurskosten kunnen worden gedekt, terwijl bij een opbrengst van 3000 pikols - de gemiddelde door ons in de voordeelige jaren verkregen oogst ter naauwernood de uitgaven, speciaal voor de kultuur benoodigd, konden worden bestreden. Intusschen werd bij Gouvernem. besluit van 30 December $1854 n_{0} .8$ Ind. Staatsbl. no 101, eene nieuwe regeling vastgesteld, waarbij bepaald werd, dat slechts door overreding en minnelijke toespraak, en alleen bij bepaalden onwil door toepassing van art. 28 der bepalingen ter regeling van eenige onderwerpen van strafzaken welke eene dadelijke voorziening vereischen, met uitzondering van rottanslagen, de planters tot hun plicht moesten worden gebracht. Het boetenstelsel werd dus afgeschaft on nu was het ook met den jiver van de hoofden voor de kultuur gedaan. Toen nu ook in 1865 het pandelingschap in Benkoelen een einde nam (Stbl. 1865 no, 1041) kon de verplichte aanplant niet meer gehandbaafd worden, de weerzin der bevolking daartegen was te sterk om dien door toespraak, hoe minnelijk ook, te overwinnen. 


\section{1}

Marar nu ook keerde rust, orde en terredenheid terug. De hoofden werden weer de eenvoudige vertegenwoordigers hunner kampongbevolking voor wier belangen zij nu enkel geroepen waren te waken; de verbroken schákel was weer gelegd, de belangen van bevolking, hoofden en bestuur stonden niet meer vijandig tegenover elkander. Toch is tot heden de toestand nog niet geheel zuiver. Hoewel de regering blijkens het voorkomende in het koloniaal verslag over $18 \% 0$, de Gouvernements peperkultuur in Benkoelen heeft opgegeven, zoo is de ordonnantie waarbij het monopolie van dat produkt aldaar is afgeschaft, nog niet uitgevaardigd. Of de peperkultuur in Benkoelen als vrije volkskultuur weer zal kunnen bloeijen, wanneer die afkondiging eerst plasts heeft nadat de laatste sporen der hier en daar nog aanwezige tuinen verdwenen zijn, zal de tijd moeten leeren.

Het bleek spoedig dat de bevolkıng van Benkoelen ontheven ran de druk der verplichte kultuur, zich van lieverlede op de teelt van andere gewassen of op meer winstgevende bedrijven, als het zoeken van damas enz. ging toeleggen en naarmate nu ook meer en gemakkelijker verkeer ontstond door verbetering der gemeenschapsmiddelen, kwam er ook meer handel en wolvaarl. De volgende eïfers van in- en uitvoer leveren hiervan het bewijs, vooral wanneer, men in aanmerking neemt dat gaandeweg de opbrengst of uitvoer van Gouvern. peper verminderde, totdat die in 1869 slechts een veertigtal pikols bedroeg.

\begin{tabular}{lll|lrr} 
& Invoer. & Uitvoer. & & Invoer. & Uitvoer. \\
1863 & 461,531 & 181,913 & 1867 & $\mathbf{6 9 5 , 8 7 0}$ & 289,036 \\
1864 & 587,824 & 225,664 & 1868 & $\mathbf{5 7 3 , 0 5 4}$ & 375,548 \\
1865 & $\mathbf{5 7 7 , 4 0 5}$ & 230,075 & 1869 & 693,192 & 391,840 \\
1866 & $\mathbf{5 7 6 , 8 1 4}$ & 220,069 & & &
\end{tabular}

$\mathrm{Na} 1808$, toen het Bantamsche rijk direkt onder het Nederlandsch gezag kwam, werden gedurende verscheidene jaren de kusten van de Lampongs onveilig gemaakt door zeeroovers, en ontstonden er ook binnen 'slands onlusten waardoor de peperkultuur bjon geheel te niet ging. $\mathrm{Na} 1858$, toen voor het eerst een geregeld bestuur in dat gewest georganiseerd werd, kwam er weer orde en veiligheid, de handel begon weer te bloeijen, en daar den landbouwer volkomen vrijheld werd gelaiven, ontwikkelde zich weer de oude volkskultuur en heeft deze thans eene hoogte bereıkt, die zeker minstens gelijk staat met rroeger en die, blijkens de belangrijke aanplantingen die jaarlijks plaats hebben, weldra eene aanzienlijke uitbreiding zal erlangen, naast de tuinen 
donr Lampongers aangelegd, even als die der Bantammers welke gelokt door de voordeelen welke de peperkultuur oplevert, zich komen vestigen in het land waar vrijherd heerscht en zekerheid van bezit. De volgende cijfers toonen aan hoo de peperkultuur vooruit is gegan.

De opbrengst was in $1856 \quad 4730$ pikols.

18657966 "

$186914855 "$

$187023000 "$

De prijs die in dit laatste jaar door de ruim 4000 planters verkregen werd, was gemiddeld $f 18$ per pikol of $f 100$ per man (*).

De 120,000 zielen sterke bevolking van de Lampongsche distrikten levert en verbruikt thans 's jaars voor eene waarde van $f 2,000,000$. Zonder bezwaar zou zij eene belasting kunnen opbrengen waarmede de bestuurskosten ruimschoots zouden kunnen worden gedekt. De medegedeelde feiten wijzen ons de koers die gevolgd en de klippen die vermeden moeten worden.

18 Junij 1872.

A. Pr. v. D. H.

(*) Het verdient opmerking dat toen in 1861 het bestuur, vermeenende in het belang van de bevolking te handelen, een drrect toezicht trachtte uit te oefenen op de koffijkultaur waarop de bevolking zich in sommige distrikten was gaan toeleggen, de koffijtuinen verlaten werden en eerst in de laatste jaren de bevolking met die kultuur weder begonnen 1s, in het vertrouwen dat het bestuur zich van alle bewoesens daarmede zal onthouden 